\title{
POTENTIAL APPLICATION OF NEW DIAGNOSTIC METHODS FOR CONTROLLING BOVINE TUBERCULOSIS IN BRAZIL
}

\author{
Luciana dos Santos Medeiros ${ }^{1}$; Carla Dray Marassi ${ }^{1}$; Eduardo Eustáquio S. Figueiredo ${ }^{2}$; Walter Lilenbaum ${ }^{1 *}$ \\ ${ }^{1}$ Laboratório de Bacteriologia Veterinária, Universidade Federal Fluminense, Niterói, RJ, Brasil; ${ }^{2}$ Universidade de Cuiabá, \\ Cuiabá, MT, Brasil.
}

Submitted: May 13, 2009; Returned to authors for corrections: August 20, 2009; Approved: February 18, 2010.

\begin{abstract}
Bovine tuberculosis, a chronic infection in cattle caused by Mycobacterium bovis, remains an economic and public health problem for several countries. Due to its economic impact on international trade, contagious nature, and implications for human health, global programs to eradicate the disease were implemented worldwide. Those programs are based on slaughtering PPD-reactive animals. Despite the National Programs in Brazil, complete eradication has not been achieved, and the disease remains, albeit at a lower prevalence.

The central purpose of this review is to address diagnostic tests for tuberculosis. Considering the course of the infection in cattle, at least two tests, ideally complementary to one another, may be necessary for an adequate diagnosis: the first based on the cellular response, and the second capable of identifying anergic animals by detection of specific anti-M.bovis antibodies.
\end{abstract}

Key words: Bovine Tuberculosis, Mycobacterium bovis, Diagnosis

\section{INTRODUCTION}

Bovine tuberculosis (BTB) is a major infectious disease among cattle in many of countries. Although cattle are the main host and reservoir of this chronic infection, other mammals, including humans, are also susceptible to Mycobacterium bovis (66).

According to the World Health Organization (WHO), BTB is a neglected, endemic zoonosis. Transmission to humans constitutes a public health problem, particularly because zoonotic TB, caused by transmission of Mycobacterium bovis to humans, is clinically identical to infection caused by Mycobacterium tuberculosis (typical TB). Since a large proportion of the world's population live in countries in which the control of bovine tuberculosis is limited or absent (78), there is consensus regarding risks to human health.

Zoonotic TB can also be considered a socio-economic disease, as it causes direct economic losses in agricultural areas and hampers commercial exchange of animal products (93). Many countries around the world enhance the control or eradication of bovine tuberculosis by National Control Programs, based on test-and-slaughter policy. Brazilian policies regarding the control and eradication of BTB include 
the National Plan for Control and Eradication of Bovine Brucellosis and Tuberculosis (PNCEBT), written in 2001 and reviewed in 2004, which is based on slaughter of all animals reactive to tuberculin tests. According to the National Control Program implemented in Brazil, treatment of reactive animals is not allowed and all reactive animals must be slaughtered (5).

Nevertheless, that traditional policy has not been fully successful, and new tools, including additional diagnostic tests and new vaccines, are urgently required (59).

The purpose of this review is to present new diagnostic approaches for BTB, which have been used to decrease the prevalence of this infection in countries where the disease still occurs.

\section{General aspects of bovine tuberculosis}

Tuberculosis lesions in cattle are most often found in organs rich in reticuloendothelial tissue, particularly the lungs and associated lymph nodes, as well as the liver (12). Other studies conducted on naturally and experimentally infected cattle demonstrated that lesions are most commonly present in the lower respiratory tract; however the upper respiratory tract and associated tissues may also display disease in many cases $(49,64)$. Although tubercles are not pathognomonic of BTB, the presence of clinical signs of the disease is directly associated to their distribution and quantity (14).

There is a lack of official data regarding the current prevalence of BTB in Brazil. Based on official reports, there was a national average prevalence of $1.3 \%$ of cows infected from 1989 to 1998 (5). Since implementation of PNCEBT in Brazil, the prevalence of the disease was reported to range from 0.7 to $3.3 \%(3 ; 53 ; 57 ; 62)$. According to the epidemiology of the disease, the higher incidence in dairy than in beef herds may affect geographic distribution. Roxo (2005) reported the rate of infection in various areas in Brazil; not surprisingly, the region with the lowest rate of infection was the one where beef herds are most predominant. Nevertheless, those data are for particular regions, and cannot be considered to provide a national context for the Brazilian herd, which includes approximately 200 million cattle (54).

\section{Immune response to $M$. bovis}

After infection, there is an initial interaction between macrophages and mycobacteria, which define subsequent events and the consequences of exposure to tubercle bacilli (58). Bacteria can be killed and eliminated from the host, lie dormant, lead to development of active tuberculosis, or reactivate from dormancy at some stage in the future (81). Apparently, members of this genus may produce spores, as Ghosh et al. (2009) recently demonstrated with Mycobacterium marinum. However, the role of that characteristic on the development of the disease has not been elucidated.

It is well established that $M$. bovis causes a delayed hypersensitivity type (DTH) reaction; T-cell recognition of mycobacterium antigens may be the major immune response to tuberculosis $(1 ; 59 ; 81)$. The DTH response is regarded as an indicator of a cellular immune response that is consequence of infection and disease due to Mycobacterium species (76).

Pollock and Neill (2002) measured the role of B-cell responses and reported that these cells induced humoral production only in advanced stages of BTB. This fact was reinforced by Welsh (2005), who documented the switch from cellular to humoral immune response in all tuberculous animals analyzed. Initially, animals developed strong antimycobacterial cell-mediated immune (CMI) responses. However, as the disease progresses, the cellular response decreases, whereas an increasing humoral response, based on IgG1 antibodies, can be clearly demonstrated. Nevertheless, the humoral response does not seem to be able to control the infection, progression of pathology, and increased bacterial load. Waters et al. (2006) reported that experimentally infected cattle also have an early antibody response, with production of IgM- and IgG-specific antibodies.

The progression of the disease may explain the anergy of some infected cattle to common CMI-based tests. The absence of CMI response in infected animals occurs particularly when the bacterial load is high (46). In human tuberculosis, lack of skin test reactivity in some individuals has been associated with an absence of lymphocyte homing receptors (58). Denis et al (2007) hypothesized that anergic cattle are a group of 
animals in which this anti-inflammatory component has been recruited, preventing the expression of markers of immunity to tuberculosis, such as bovine PPD responsiveness. Recent data in a bovine model of tuberculosis infection suggested there is an appreciable release of IL-10 associated with disease progression, strengthening the involvement of IL-10 in PPD anergy. Failure to develop a response to PPD may also be linked to an enhanced activation profile of monocytes or macrophages, notably the release of high levels of reactive nitrogen and/or oxygen intermediates or prostaglandins, reducing T-lymphocyte proliferation and/or cytokine release (15).

\section{DIAGNOSIS}

There is a growing perception that no single method is sufficient for detecting all cattle infected with BTB (74); therefore, a multidisciplinary approach must be employed, based on current available methods. Some of the interactions among various diagnostic methods regularly used for diagnosing BTB are shown (Figure 1).

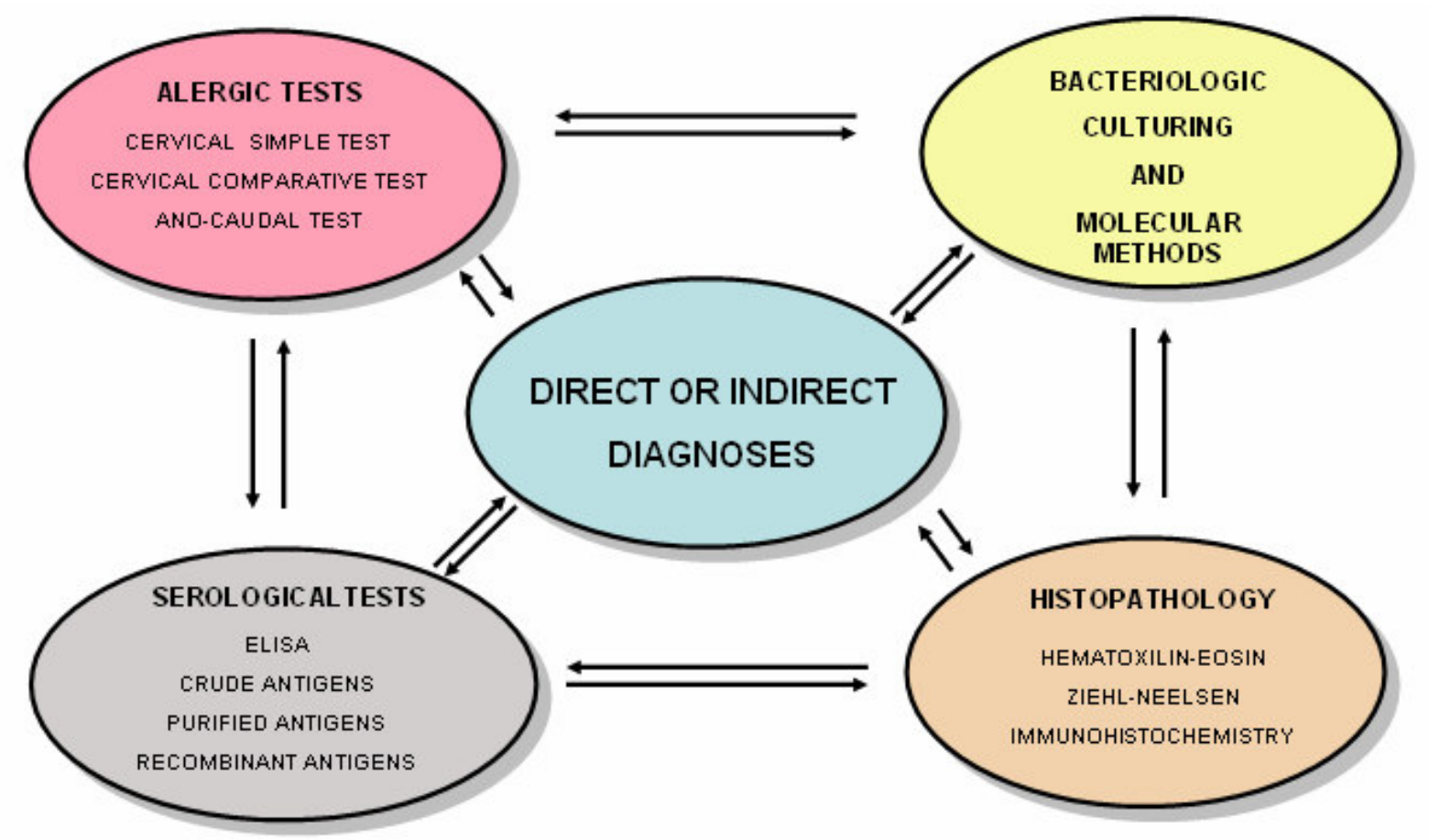

Figure 1. Interactions among various methods currently used for the diagnosis of bovine tuberculosis.

\section{DIRECT METHODS - EVIDENTIATION OF THE \\ AGENT}

\section{Direct examination of smears}

Although microscopic examination of smears is faster and cheaper than any other method, visualization of acid-fast bacilli (AFB) is not able to discriminate among members of the Mycobacteriaceae family, or between members of the genus Mycobacterium and other organisms which share this acid-fast staining characteristic, including certain species of Legionella, Nocardia, Rhodococcus, Tsulunnurella, Cryptosporidium, and Cyclospora (19). Additionally, this method lacks sensitivity (79) and can only reveal the presence of AFB when concentrations are exceeding $10^{4}$ bacteria per milliliter (65). Due to its low specificity (thereby leading to false negatives) and difficulties in obtaining sputum from animals, the direct examination is not usually employed as a diagnostic method for BTB. 


\section{Bacteriological Culture}

Techniques used in veterinary laboratories to isolate $M$. bovis differ from those used in medical laboratories, mainly because the strains of $M$. bovis grow poorly or not at all on the glycerol-based media traditionally used to culture $M$. tuberculosis. Therefore, media containing sodium pyruvate, in lieu of glycerol, are used for isolation of M. bovis (83). Furthermore, it is generally accepted that mycobacteria grow more rapidly in liquid medium (74).

The genus Mycobacterium is highly exigent regarding its need for nutrients, whereas other microorganisms will multiply easier and faster than mycobacterium. Samples collected from sputum, milk, or suspected tissue lesions should be submitted to decontamination methods to eliminate such competitive microorganisms. Pretreatment or decontamination of samples involves the addition of 1 to $5 \% \mathrm{NaOH}$, often followed by further treatments with $\mathrm{H}_{2} \mathrm{SO}_{4}$, oxalic acid, or quaternary ammonium compounds (91). Samples can be also be decontaminated also with $0.75 \%$ cetylpyridinium chloride (CPC) $(11 ; 52)$. Unfortunately, the toxic effects of decontamination may affect mycobacterial viability, thereby interfering with culturing the organism (33).

Growth of $M$. bovis may take up to 6-8 weeks (79). On a suitable pyruvate-based solid medium, colonies are smooth and off-white. Although characteristic growth patterns and colonial morphology can provide a presumptive diagnosis of $M$. bovis, every isolate needs to be confirmed (52). The identification is made in two steps: the first is to obtain a primary culture of the bacillus, and the second is identification, based on physiological and biochemical characteristics (77).

Biochemical testing requires an additional two to four weeks after mycobacteria colonies have appeared in culture (74). Although isolation of M. bovis can be used to confirm infection, the difficulty of obtaining representative samples from live animals, the need for pretreatment, slow growth, and additional time for biochemical identification, are limitations of this method.

\section{Histopathology and Immunohistological examination}

Lesions of bovine tuberculosis are typically characterized by the presence of tubercles with central caseation and calcification. In the early stages of infection, these lesions are not encapsulated, but are surrounded by condensed alveolar tissue. Initially, there is the presence of epitheloid and giant cells at the center of the tubercle, and, as the disease progress, they are surrounded by lymphocytes, plasma cells and monocytes, developing a peripheral fibroplasia and central caseous necrosis (50).

Histological examinations are practical and inexpensive, and useful to make decisions on grossly suspect carcasses (79). Another advantage of histopathology is increased diagnostic sensitivity when it is performed in conjunction with culture (38). Fráguas et al. (2008) examined 97 tuberculin-reactive animals and tested the value of histological examination as a complementary tool. In that study, $64.9 \%$ of the samples had characteristic lesions, with concordance among macroscopic evaluation, histological examination, and microscopy. This high concordance could be a consequence of a correct carcass gross examination. Despite those advantages, the requirement for obtaining postmortem samples limits the diagnostic process (42), and most lesions can be paucibacillary (38), leading to false-negative results.

The immunohistological examination is more sensitive than the traditional Ziehl-Neelsen technique. In addition to being a diagnostic tool, it also provides information regarding host immune responses (59). Immunological approaches include the use of cell markers $(2,47)$, cytokines $(2,36)$, Mycobacterium cell-wall antigens (60), and adhesion molecule markers (47). Various anti-BCG antibodies for immunohistochemistry are commercially available, but Purohit et al. (2007) demonstrated that the use of anti-MTP-64, a specific antigen for $M$. tuberculosis complex, seems to be a more sensitive and specific marker.

\section{Molecular assays}

The use of molecular assays to diagnose bovine tuberculosis has improved substantially in the last few years (56). Furthermore, advances in molecular characterization have also provided new tools to enhance the knowledge of $M$. bovis epidemiology and tuberculosis control. In a comprehensive 
review, Neonakis et al. (2008) discussed several molecular techniques that have been developed for direct detection of mycobacteria from clinical samples, based on amplification of unique mycobacterial DNA or RNA target fragments by PCR. Tests can be done on sputum, blood, nasal swabs, and other tissues, with the advantage of rapidly detecting non-viable bacilli (68). However, its use for paucibacillary samples has limitations regarding sensitivity $(68,72)$. In Brazil, Zanini et al. (2001), Leite et al. (2003), Figueiredo (2006), and Figueiredo et al. (2008a, 2008b), employed PCR techniques for identification of $M$. bovis from tissues, milk and colonies, demonstrating that those tests can be valuable to rapidly identify isolates with the minimum of $10 \mathrm{CFU} / \mathrm{mL}$ limit of $M$. bovis in milk.

In addition, PCR-based techniques, such as spoligotyping, can be used for identifying $M$. bovis within the $M$. tuberculosis complex (lack of spacers 3, 9, 16, and 39-43) (16). A low IS6110 copy number in $M$. bovis can positively influence the results, with good discriminatory power $(7,18)$. Spoligotyping can also improve the discriminatory power of IS6110 restriction length polymorphism (RFLP) typing $(25,93)$.

Molecular assays have been primarily used to analyze the epidemiology of bovine tuberculosis; various strains, including laboratory and clinical samples, have been successfully employed $(13,30,35,56,65,93)$. In that regard, PCR-based characterization techniques, such as spoligotyping and mycobacterial interspersed repetitive unit (MIRU) variablenumber tandem repeat (VNTR) typing, have been adopted due to their various advantages, including faster, simpler, and more cost-effective (67). It can provide an analysis of organism dispersion due to surveillance of reactive animals to tuberculin tests, characterizing samples, and explaining patterns found in various herds or regions. Furthermore, molecular epidemiology of the disease can be used to monitor and control animal trade, and to assess the efficacy of eradication programs.

\section{INDIRECT METHODS}

\section{Tuberculin intradermal tests}

Tuberculinisation, or intradermal tuberculin tests, have been used for more than 100 years, and are currently the method most widely used for diagnosing BTB in cattle (48). The test, also known as single cervical intradermal tuberculin test (SITT), is based on an injection of a purified protein derivative (PPD) of $M$. bovis origin (bovPPD). When performed in parallel to the injection of PPD of M. avium PPD (avPPD), the test is known as the comparative cervical intradermal tuberculin test (CITT). Seventy-two hours after injection, the skin thickness is measured with calipers, as skin swelling is a measure of hypersensitivity to the antigens used (5).

Cattle infected with M. avium, M. tuberculosis, M. avium paratuberculosis, Nocardia farcinius, or other mycobacteria could be reactive to bovine PPD, leading to false-positive results. As mycobacteria shares several antigens, cross reactions are common, reducing test specificity. Therefore, comparative intradermal tests are performed with the purpose of reducing the occurrence of such cross reactions; however, this approach does not completely eliminate nonspecific reactions (10).

Despite the broad usage of this assay, tuberculinisation sensitivity reports range from 68 to $95 \%$, whereas specificity (for CITT) ranges from 96 to $99 \%$. Another disadvantage is the requirement for two visits to the herd within 72 hours (48), making the diagnosis more expensive, laborious, and subject to fraud (42). Frequently, using skin tests as the sole diagnostic tool does not detect all infected animals (38); some anergic animals could be a reservoir of the bacteria, which could compromise elimination of the main sources of infection.

\section{Assays based on cellular immunity}

It is well established that the immune response of mycobacterial infections is predominantly cellular, at least initially. Therefore, early diagnostic techniques should be based preferentially on measurement of $\mathrm{T}$ lymphocyte responses (88). Limitations of the intradermal tuberculin tests lead to the development of other diagnostic tests. Wood et al. (1990a) developed a rapid (24 hour) in vitro cellular assay for bovine tuberculosis, based on the detection of $\gamma$ interferon $(\gamma-$ 
IFN), which is released in response to specific antigens in whole-blood culture. The production of monoclonal antibodies for specific bovine $\gamma$ - IFN facilitated development of a sandwich enzyme immunoassay (ELISA) for bovine $\gamma$ - IFN $(69,90)$.

The bovine $\gamma$ - IFN ELISA (IFN) can also identify some tuberculous skin test-negative cattle, since it is capable of detecting cases in very early stages of infection $(28,49)$. Cagiola et al (2004) reported specificity higher than the skin test, ranging from 97.3 to $98.6 \%$ depending on the tuberculin used. In Brazil, Lilenbaum et al (1999b) compared IFN to the intradermal tuberculin test under field conditions for the diagnosis of bovine tuberculosis, and reported that the sensitivity of the IFN was higher than the SCITT skin test (sensitivities were 100 and $88.3 \%$, respectively).

The IFN requires animals be handled only once. Furthermore, since lymphocyte stimulation is carried out in vitro and the animal is not inoculated with PPD (82), this test can be repeated as often as desired. Since the interpretation of results is based on numerical values, this test is more objective than hypersensitivity reactions measured in the skin. However, disadvantages of using IFN are the need for processing the sample in well-equipped laboratories, and the cost of conducting each test, which is higher than skin tests (42).

The effects of prior tuberculisation on the results of the IFN test have been widely studied. Rothel et al. (1992) reported that the application of tuberculin tests to infected cattle reduced $\gamma$ - IFN responses for seven days period, with a gradual response enhancement over 60 days. Subsequent work by Wood and Rothel (1994) supported these findings. Nevertheless, other studies $(17,29,76)$ did not found any significant impact of a previous tuberculin test on interpretation of an IFN assay. Ryan et al. (2000) demonstrated that this assay could be done in tuberculin-sensitized animals eight to 28 days after the inoculation of PPD, and that the results could be complementary to the skin test. Those apparently conflicting reports may be due to the variable conditions under which the studies were conducted (55), nature and stage of infection, numbers of animals recruited, skin protocols, and interpretation criteria of the assay (28). In Brazil, the use of IFN as a confirmatory tool for cows with inconclusive results on tuberculin tests was recently demonstrated (45). When applied seven or 21 days after injection of PPD, sensitivity was 74.3 and $71.4 \%$, respectively, whereas specificity was 86.7 and $80 \%$. Therefore, it was concluded that the IFN assay could be effectively used as a confirmatory test seven or 21 days after injection of PPD.

\section{Serological assays}

It is well established that cattle infected by $M$. bovis develop early immune responses, dominated by cell-mediated immunity $(1,20,46,59,81)$. Therefore, serology is less efficient to identify cattle in the early stages of infection, when antibodies titres are low (88).

There are several advantages to using serological methods, e.g. ELISA, for the diagnosis of BTB. These tests require only one handling of the animals and only one visit of the veterinarian to the farm. Blood sampling can be repeated as often as necessary, without altering the immune status of the animal. That the interpretation is based on numerical values makes it more objective than the observation of swelling of the skin (41). The indirect ELISA technique measures the binding of specific antibodies to an antigen (43). In order to diagnose cattle infected by $M$. bovis, antigens usually employed are the PPD and single or associated purified antigens from $M$. bovis $(21,41,43,75,80)$.

Regarding purified M. bovis antigens, Ag85 complex represents a major part of the secreted proteins $(85,87)$. Nevertheless, antibodies directed against those antigens may also be present in non-infected individuals (85), leading to false positives. In Brazil, Lilenbaum et al (2001) used an ELISA with the Ag85 as its capture antigen and achieved a sensitivity of $91.3 \%$ and specificity of $94.8 \%$. Although other studies reported high specificity, the sensitivity of ELISAs systems employing this antigen were lower $(21,32,34,59)$.

The MPB70 protein, which represents approximately 10\% of the PPD (85), has been identified as a B-cell target in tuberculous cattle (39) and also as a reasonably specific protein 
(4, 31, 61). It has been suggested that MPB70 and its highly homologous protein MPB83, secreted mycobacterial proteins with limited species distribution, are both involved in host protein cell binding (9). These proteins are highly expressed in M. bovis, but minimally expressed in M. tuberculosis in vitro and probably in vivo (86). Wiker et al (1998) demonstrated the diagnostic potential of these proteins, and reported that most monoclonal antibodies identify shared epitopes on these molecules, and that the linear epitopes of MPB70 were the major antibody targets, both upon immunization with protein preparations and during infection with M. bovis. Although MPB83 present some minor differences in comparison with the MPB70, new studies demonstrated the usefulness of the MPB83 to diagnose tuberculosis earlier than MPB70 in experimentally infected animals. In that regard, MPB83ELISAs detected specific antibodies four weeks post infection, whereas MPB70-ELISAs detect specific antibodies 18-22 months after experimental infection (84).

Furthermore, ELISAs using MPB70 as capture antigens have good specificity ( 88 to $96 \%$ ), whereas sensitivity was quite variable, ranging from 18 to $73 \%$ (84) That MPB70 has some cross-reactivity with Nocardia was the impetus to test specific epitopes of the protein, in an attempt to increase the test specificity $(39,61)$. Furthermore, rM70-83-E6, a recombination of antigens MPB70, MPB83 and ESAT-6, specifically reacts with bovine tuberculosis-positive sera, also improving ELISA sensitivity and specificity (44).

Employing bovine PPD as capture antigen in ELISA, Ritacco et al. (1987) reported 90\% sensitivity and $89.8 \%$ specificity for diagnosis of BTB. Furthermore, in other studies using the same test, Casillas et al. (1995) reported $76.5 \%$ of sensitivity in Mexico, whereas Lilenbaum et al. (1999a) reported $86.7 \%$ sensitivity and $90.6 \%$ specificity in dairy herds in Rio de Janeiro, Brazil.

Perhaps recombinant antigens are not antigenically identical to their native counterpart; therefore, they may not be recognized by the immune system of infected animals (21). Silva (2001) reported increased sensitivity in proportion to the number and distribution of lesions found in the anatomopathological tests, suggesting that the sensitivity of ELISA depends on the duration and severity of herd infection.

Although serological assays cannot be considered first choice diagnostic methods, many researchers describe strategies for their use $(14,40,75)$. Their recommendations are based on the existence of anergic animals $(46,75)$, as well as increased antibody titres in more advanced stages of the disease $(58,81)$. Using ELISA, Lilenbaum \& Fonseca (2006) identified tuberculous cows in 18 herds involved on a tuberculosis control program, and subsequently confirmed infection by isolation of $M$. bovis from lung lesions. In those cases, ELISA was employed as a complementary diagnostic test and improved the control of tuberculosis by identifying anergic cows.

\section{CONCLUSION}

Despite all the efforts to control BTB, the disease persists, with serious implications for human health and the economy, particularly in the context of global trade. The current available skin tests, when correctly conducted, provide satisfactory results. Nevertheless, in order to improve the control of the disease, complementary tests may be required, particularly in the final stages of eradication programs, when the occurrence of false reactive animals to skin tests is higher. The existence of anergic animals is also a challenge for the diagnosis and control of the disease. Due to the particular and complex characteristics of BTB, there is growing perception that no single method by itself is sufficient for detecting all the reactive animals in every stage of infection. Therefore, a multidisciplinary approach must be conducted, using various categories of currently available methods. In a modern approach for diagnosis and control of BTB, bacteriological, molecular, histopathological, and immunological assays must be employed, considering the indications, advantages, and disadvantages, of each method.

\section{ACKNOWLEDGEMENTS}

The authors are thankful to Prof. J. Kastelic (Canada) for the critical review and corrections on the manuscript. 


\section{REFERENCES}

1. Alito, A.; McNair, J.; Girvin, R.M.; Zumarraga, M.; Bigi, F.; Pollock, J.M.; Cataldi, A. (2003). Identification of Mycobacterium bovis antigens by analysis of bovine T-cell responses after infection with a virulent strain. Braz. J. Biol. Res. 36 (11), 1523-1531.

2. Bai, X.; Wilson, S.E.; Chmura, K.; Feldman, N.E.; Chan, E.D. (2004). Morphometric analysis of $\mathrm{Th}_{1}$ and $\mathrm{Th}_{2}$ cytokine expression in human pulmonary tuberculosis. Tuberculosis $84(6), 375-385$

3. Baptista, F.; Moreira, E.C.; Santos, W.L.M; Naveda, L.A.B. (2004). Prevalência da tuberculose em bovinos abatidos em Minas Gerais/ Prevalence of tuberculosis among bovines slaughtered in Minas Gerais, Brazil. Arq. Bras. Med. Vet. Zootec. 56 (5), 577-580.

4. Billman-Jacobe, H.; Radford, A.J.; Rothel, J.S.; Wood, P.R. (1990). Mapping of the $\mathrm{T}$ and $\mathrm{B}$ cell epitopes of the Mycobacterium bovis protein, MPB 70. Immunol. Cell Biol. 68 (6), 359-365.

5. BRASIL. (2006). Ministério da Agricultura Pecuária e Abastecimento do Brasil. Programa Nacional de Controle e Erradicação da Brucelose e Tuberculose Animal (PNCEBT)/ National Program for the Control and Eradication of Bovine Brucellosis and Tuberculosis - MAPA/DAS/DAS, $188 \mathrm{p}$.

6. Cagiola, M.; Feliziani, F.; Severi, G.; Pasquali, P.; Rutili, D. (2004). Analysis of possible factors affecting the specificity of the gamma interferon test in tuberculosis-free cattle herds. Clin. Diag. Lab. Immun., 11(5), 952-956.

7. Caimi, K.; Romano, M.I.; Alito, A.; Zumarraga, M.; Bigi, F.; Cataldi, A. (2001). Sequence analysis of the direct repeat region in Mycobacterium bovis. J. Clin. Microbiol., 39(3),1067-72.

8. Casillas, C.R.; Elizondo, G.V.; Diaz, C.A. (1995). Comparición del ELISA con la tuberculinizacion en el diagnostico de la tuberculosis bovina (Comparition of ELISA and the tuberculin test in the diagnosis of bovine tuberculosis). Tec. Pec. Mex. 33 (3), 148-158.

9. Chambers, M.A.; Gavier-Widén, D.; Hewinson, R.G. (2004). Antibody bound to the surface antigen MPB83 of Mycobacterium bovis enhances survival against high dose and low dose challenge FEMS Immunol. Med. Microbiol. 41(2), 93-100.

10. Collins, D.M.; Radford, A.J.; de Lisle, G.W.; Jacob, H.B. (1994). Diagnosis and epidemiology of bovine tuberculosis using molecular biological approaches. Vet. Microbiol. 40 (1-2), 83-94.

11. Corner, L.A. (1994). Post mortem diagnosis of Mycobacterium bovis infection in cattle. Vet. Microbiol. 40 (1-2), 53-63.

12. Corner, L.A.; Melville, L.; McCubbin, K.; Small, K.J.; McCormick, B.S.; Rothel, J.S. (1990). Efficiency of inspection procedures for detection of tuberculous lesions in cattle. Aust. Vet. J. 67 (11), 389-392

13. Cousins, D.V.; Williams, S.N.; Ross, B.C.; Ellis, T.M. (1993). Use of a repetitive element isolated from Mycobacterium tuberculosis in hybridization studies with Mycobacterium bovis: a new tool for epidemiological studies of bovine tuberculosis. Vet. Microbiol. 37 (1-2), $1-17$.
14. de la Rua Domenech, R.; Goodchild, A.T.; Vordemeier, H.M.; Hewinson, R.G.; Christiansen, K.H.; Clifon-Hadley, R.S. (2006). Ante mortem diagnosis in cattle: A review of the tuberculin tests, $\gamma$-interferon assay and other ancillary diagnostic techniques. Res. Vet. Sci. 81 (2), 190210.

15. Denis, M.; Wedlock, D. N.; McCarthy, A.R.; Parlane, N.A.; Cockle, P.J.; Vordermeier, H. M.R.; Hewinson, G.; Buddle B.M. (2007). Enhancement of the sensitivity of the whole-blood gamma interferon assay for diagnosis of Mycobacterium bovis Infections in cattle. Clin. Vac. Immunol. 14(11), 1483-1489.

16. Djaibé,C.D.; Hilty,M.; Ngandolo,R; Mahamat, H.H.; Pfyffer, G.E.; Franca,B.; Hewinson,G.; Tanner, M.; Zinsstag,J.; Schelling, E. (2006). Mycobacterium bovis Isolates from tuberculous lesions in Chadian zebu carcasses. Emerg. Infect. Dis. 12(5), 769-71.

17. Doherty, M.L.; Monaghan, M.L.; Bassett H.F.; Quinn, P.J. (1995). Effect of a recent injection of purified protein derivative on diagnostic tests for tuberculosis in cattle infected with Mycobacterium bovis Res. Vet. Sci. 58(3), 217-221

18. Duarte, E.L.; Domingos, M.; Amado, A.; Botelho, A. (2008). Spoligotype diversity of Mycobacterium bovis and Mycobacterium caprae animal isolates. Vet. Microbiol. 130 (3-4), 415-421.

19. Eisenstadt, J.; Hall, G.S. (1995). Microbiology and classification of mycobacteria. Clin. Dermatol. 13 (3), 197-206.

20. Fifis, T.; Corner, L.A; Rothel, J.S.; Wood, P.R. (1994a) Cellular and humoral responses of cattle to purified Mycobacterium bovis antigens. Scand. J. Immunol. 39 (3), 267-274.

21. Fifis, T.; Rothel, J.S.; Wood, P.R. (1994 b). Soluble Mycobacterium bovis protein antigens: Studies on their purification and immunological evaluation. Vet. Microbiol. 40 (1-2), 65-81.

22. Figueiredo, E.E.S.; Silva, M.G.; Fonseca, L.S.; Silva, J.T. Paschoalin, V.M.F. (2008b). Detecção de Mycobacterium bovis no leite através da identificação do complexo M. tuberculosis por PRA (Detection of Mycobacterium bovis in milk by identification of $M$. tuberculosis complex by PRA). C. Anim. Bras. In press.

23. Figueiredo, E.; Silvestre, F.G.; Campos, W.N.; Furlanetto, L.; Medeiros, L.; Lilenbaum, W.; Fonseca, L. S.; Silva, J.T.; Paschoalin, V. (2008a) Identification of Mycobacterium bovis Isolates by a multiplex PCR. Braz. J. Microbiol. 40(2), 231 - 233.

24. Figueiredo, E.E.S. (2006). Padronização de técnicas moleculares para detecção de Mycobacterium bovis em leite: uma questão de saúde pública (Standardization of molecular techniques for the detection of Mycobacterium bovis in milk: A matter of public health). Rio de Janeiro, Brazil (Msc. Dissertation. Instituto de Química. UFRJ).

25. Flores, L.; Van, T.; Narayanan, S.; DeRiemer, K.; Maeda, M.K.; Gagneux, S. (2007). Large sequence polymorphisms classify Mycobacterium tuberculosis strains with ancestral spoligotyping patterns. J Clin Microbiol. 45 (10), 3393-3395.

26. Fráguas, S.A.; Cunha-Abreu, M.S.; Ferreira, A.M.R.; Marassi, C.D.; Oeleman, W.M.R.; Fonseca, L.S.; Ferreira, R.; Lilenbaum, W. (2008). 
Estudo comparativo de métodos complementares para o diagnóstico da tuberculose bovina em animais reagentes à tuberculinização (Comparative study on complementary methods for the bovine tuberculosis diagnosis in animals reactive to the intradermal tests). Rev. Bras. C. Vet. 15 (3), 117-121.

27. Ghosh, J.; Larsson, P.; Singh, B.; Pettersson, B.M.; Islam, N.M.; Sarkar, S.N.; Dasgupta, S.; Kirsebom, L.A. (2009). Sporulation in mycobacteria. Proc. Natl. Acad. Sci. U S A. 106(26), 10781-6.

28. Gormley, E.; Doyle, M.B.; Fitzsimons, T.; McGill, K.; Collins, J.D. (2006). Diagnosis of Mycobacterium bovis infection in cattle by use of gamma-interferon (Bovigam) assay. Vet. Microbiol. 112 (2-4), 171-179.

29. Gormley, E.; Doyle, M.B.; McGill, K.; Costello, E.; Good, M.; Collins, J.D. (2004). The effect of the tuberculin test and the consequences of a delay in blood culture on the sensitivity of a gamma-interferon assay for the detection of Mycobacterium bovis infection in cattle Vet. Immunol. Immunopathol. 102 (4), 413-420

30. Griffin, J.M.; Dolan, L.A. (1995).The role of cattle-to cattle transmission of Mycobacterium bovis in the epidemiology of tuberculosis in cattle in the republic of Ireland: A review. Ir. Vet. J. 48, 228-234.

31. Harboe, M.; Nagai, S.; Patarroyo, M.E.; Torres, M.L.; Ramirez, C.; Cruz, N. (1986). Properties of proteins MPB 64, MPB 70, and MPB 80 of Mycobacterium bovis BCG. Infect. Immun., 52(1), 293-302.

32. Harboe, M.; Wiker, H.G.; Ulvind, G.; Pedersen, B.; Andersen, A.B.; Hewinson, R.G.; Nagai, S. (1998). MPB70 and MPB83 as indicators of protein localization in mycobacterial cells. Infect. Immun. 66, 289-296.

33. Holanda, E.D.; Lobato, F.C.; Mota, P.M.; Abreu, V.L. (2002). Avaliação de métodos de descontaminação para isolamento de Mycobacterium bovis (Evaluation of decontamination methods for Mycobacterium bovis isolation). R. Bras. Med. Vet. 24 (2), 54-57.

34. Juárez, M.D.; Torres, A.; Espitia, C. (2001). Characterization of Mycobacterium tuberculosis region containing the mpt83 and mpt70 genes. Microbiol. Lett., 203 (1), 95-102.

35. Kamerbeek, J.; Schouls, L.; Kolk, A.; van Agterveld, M.; van Soolingen, D.; Kuuper, S.; Bunschoten, A.; Molhuizen, H, Shaw; R., Goyal, M.; van Embdem, J. (1997). Simultaneous detection and differentiation of Mycobacterium tuberculosis for diagnosis and epidemiology. J. Clin. Microbiol. 35 (4), 907-914

36. Kiszewski, A.E.; Becerril, E.; Aguilar, L.D.; Kader, I.T.A.; Myers, W.; Portaels, F.; Pando, R.H. (2006). The local immune response in ulcerative lesions of Buruli disease. Clin. Exp. Immunol. 143(3), 445451.

37. Leite, C.Q.F.; Anno, I.S.; Leite, S.R.A.; Roxo, E.; Morlock, G.P.; Cooksey, R.P. (2003). Isolation and identification of mycobacteria from livestock specimens and milk obtained in Brazil. Mem. Inst. Oswaldo Cruz, 98 (3), 319-323.

38. Liebana, E.; Johnson, J.; Gough, J.; Durr., P.; Jahans, K.; Clifton-Hadley, R.; Spencer, Y.; Hewinson, R.G.; Downs, S.H. (2008). Pathology of naturally occurring bovine tuberculosis in England and Wales. Vet. J. 176 (3), 354-360.
39. Lightbody, K.A.; McNair, J.; Neill, S.D.; Pollock, J.M. (2000). IgG isotype antibody responses to epitopes of the Mycobacterium bovis protein MPB70 in immunised and in tuberculin skin test-reactor cattle Vet. Microbiol. 75 (2), 177-188.

40. Lilenbaum, W.; Fonseca, L. (2006). The use of ELISA as a complementary tool for bovine tuberculosis control in Brazil. Braz. J. Vet. Res. Anim. Sci. 43 (2), 256-261.

41. Lilenbaum, W.; Fonseca, L.S.; Pessolani; M.C.V. (2001). The use of Ag85 complex as antigen in ELISA for the diagnosis of bovine tuberculosis in dairy cows in Brazil. J. Vet. Med. 48 (3), 161-166.

42. Lilenbaum, W.; Schettinni, J.; Souza, G.N.; Ribeiro, E.R.; Moreira, E.C. (1999). Comparison between a gama- IFN assay kit and intradermal tuberculin test for the diagnosis of bovine tuberculosis on field trials in Brazil. J. Vet. Med. 46 (5), 353-358.

43. Lilenbaum, W.; Schettini, J.C.; Ferreira, M.A.S.; Souza, G.N.; Ribeiro, E.R.; Moreira, E.C.; Fonseca, L.S. (1999). Evaluation of an ELISA - PPD for the diagnosis of bovine tuberculosis in field trials in Brazil. Res. Vet. Sci. 66, 191-195.

44. Liu, S.; Guo, S.; Wang, C.; Shao, M.; Zhang, X.; Guo, Y.; Gong, Q.A. (2007). Novel fusion protein-based indirect enzyme-linked immunosorbent assay for the detection of bovine tuberculosis. Tuberculosis 87 (3), 212-217

45. Marassi, C.D.; Medeiros, L.; Lilenbaum, W. (2009). The use of a Gamma-Interferon assay to confirm a diagnosis of bovine tuberculosis. Acta Trop. In press.

46. McNair, J.; Corbett, D.M.; Girvin, R.M.; Mackie, D.P.; Pollock, J.M. (2001). Characterization of the early antibody response in bovine tuberculosis: MPB 83 is an early target with diagnostic potential. Scand. J. Immunol. 53, 365-371.

47. Miranda, A.; Amadeu, T.P.; Schueler, G.; Alvarenga, F.B.F.; Duppré, N.; Ferreira, H.; Nery, J.A.C.; Sarno, E.N. (2007). Increased Langerhans cell accumulation after mycobacterial stimuli. Histopathology 51(5), 649656.

48. Monaghan, M.L.; Doherty, M.L.; Collins, J.D.; Kazda, J.F.; Quinn P.J. (1994). The tuberculin test. Vet. Microbiol. 40 (1-2), 111-124.

49. Neill, S.D.; Cassidy, J.; Hanna, J.; Mackie, D.P.; Pollock, J.A.; Clements, A.; Walton, E.; Bryson, D.G. (1994). Detection of Mycobacterium bovis infection in skin test-negative cattle with an assay for bovine interferongamma. Vet. Rec. 135 (6), 134-135.

50. Neill, S.D.; Pollock, J.M.; Bryson, D.B.; Hanna, J. (1994). Pathogenesis of Mycobacterium infection in cattle. Vet. Microbiol. 40 (1-2), 41-52.

51. Neonakis, K.I.; Gitti, Z.; Krambovitis, E.; Spandidos. A.D. (2008). Molecular diagnostic tools in mycobacteriology. J. Microbiol. Methods, $75(1), 1-11$.

52. OIE, World Organization for Animal Health. Terrestrial Manual, (2008). http://www.oie.int/eng/normes/mmanual/2008/pdf/2.04.07_BOVINE_TB .pdf. Acessed 11 May 2009.

53. Oliveira, I.; Melo, H.; Câmara, A.; Dias, R.; Soto-Blanco, B. (2007). 
Prevalência de tuberculose no rebanho bovino de Mossoró, Rio Grande do Norte (Prevalence of bovine tuberculosis in a bovine herd from Mossoró, Rio Grande do Norte). Braz. J. Vet. Res. Anim. Sci., 44 (6), 395-400,

54. PAHO/WHO, Centro Panamericano de Fiebre Aftosa. Informe de Situação de Países. (2006). http://bvs.panaftosa.org.br/docs/level2.php? channel=textoc\&lang=es. Acessed 22 Jan 2009

55. Palmer, M.V.; Waters, W.R.; Thacker, T.C.; Greenwald, R.; Esfandiari, J.; Lyashenko, K.P. (2006). Effects of different tuberculin skin-testing regiments on gamma interferon and antibody responses in cattle experimentally infected with Mycobacterium bovis. Clin. Vaccine Immunol. 13 (3), 387-394.

56. Parra, A.; García, N.; García, A.; Lacombe, A.; Moreno, F.; Freire, F.; Moran, J.; Hermosa de Mendoza, J. (2008). Development of a molecular diagnostic test applied to experimental abattoir surveillance on bovine tuberculosis. Vet. Microbiol. 127 (3-4), 315-324.

57. Poletto, R.; Kreutz, L.C.; Gonzales, J.C.; Barcellos, L.J.G. (2004). Prevalência de tuberculose, brucelose e infecções víricas em bovinos leiteiros do município de Passo Fundo, RS (Prevalence of tuberculosis, brucelosis and viral infections in dairy cattle from the county of Passo Fundo, RS, Brazil). Ciência Rural; 34(2), 595-598.

58. Pollock, J.M. \& Neill, S.D. (2002). Mycobacterium bovis infection and tuberculosis in cattle. Vet. J. 163 (2), 115-127.

59. Pollock, J.M.; Welsh, M.D.; McNair, J. (2005). Immune Response in bovine tuberculosis: Towards new strategies for the diagnosis and control of disease. Vet. Immunol. Immunopathol. 108 (1-2), 37-43.

60. Purohit, M.R.; Mustafa, Tehmina T.; Wiker, H.G.; Mørkve, H.G.O.; Sviland, L. (2007). Immunohistochemical diagnosis of abdominal and lymph node tuberculosis by detecting Mycobacterium tuberculosis complex specific antigen MPT64. Diag. Pathol. 2 (1), 36.

61. Radford, A.J.; Wood, P.R.; Billman-Jacob, H.; Geysen, M.; Mason, T.M.; Tribbick, G. (1990). Epitope mapping of the Mycobacterium bovis secretory protein MPB 70 using overlapping peptide analysis. J. Gen. Microbiol. 136 (2), 265-272.

62. Ribeiro, A.R.P.; Lobato, F.C.F.; Abreu, V.L.V.; Faria, E.S.; Silva, J.A. (2003). Prevalência de tuberculose e brucelose bovina no município de Ilhéus/ Prevalence of bovine tuberculosis and brucellosis in Ilhéus, Bahia - Brazil. Arq. Bras. Med. Vet. Zootec. 55(1), 120-122.

63. Ritacco, V.; Kantor, I.N. ; Barrera, L.; Nader, A.; Bernadelli, A.; Torrea, G.; Errico, F.; Fliess, E. (1987). Assessment of the sensivity and specificity of ELISA for the detection of Mycobacterial antibodies in bovine tuberculosis. J. Vet. Med. 34 (2), 119-125.

64. Rodgers, J.D.; Connery, N.L.; McNair, J.; Welsh, M.D.; Skuce, R.A.; Bryson, D.G.; McMurray, D.N.; Pollock, J.M. (2007). Experimental exposure of cattle to a precise aerosolized challenge of Mycobacterium bovis: A novel model to study bovine tuberculosis. Tuberculosis 87 (5), 405-414.

65. Rodriguez, C.A.R.; Zumárraga, M.J.; Oliveira, E.M.D.; Cataldi, A.A.; Romano, M.I.; Otto, H.H.; Bonafé, V.L.; Ferreira Neto, J.S. (2004).
Caracterização molecular de isolados de Mycobacterium bovis do Estado de São Paulo Brasil, utilizando a técnica de spoligotyping (Molecular characterization of Mycobacterium bovis isolates from the state of São Paulo, Brazil, using the technique of spoligotyping). Arq. Inst. Biol., 71 (3), 277-282.

66. Romano, M.I.; Alito, A.; Fisanotti, J.C.; Bigi, F.; Kantor, I.; Cicuta, M.E.; Cataldi, A. (1996). Comparison of different genetic markers for molecular epidemiology of bovine tuberculosis. Vet. Microbiol. 50 (1-2), 59-71.

67. Romero, B.; Aranaz, A.; Juan, L.; Álvarez, J.; Bezos, J.; Mateos, A.; Mampaso, E.G.; Domínguez, L. (2006). Molecular epidemiology of multidrug-resistant Mycobacterium bovis isolates with the same spoligotyping profile as isolates from animals. J. Clin. Microbiol. 44(9), 3405-3408.

68. Roring, S.; Hughes, M.S.; Skuce, R.A.; Neill, S.D. (2000). Simultaneous detection and strain differentiation of Mycobacterium bovis directly from bovine tissue specimens by spoligotyping. Vet. Microbiol. 74 (3), 227236.

69. Rothel, J.S.; Jones, S.L.; Corner, L.A.; Cox, J.C.; Wood, P.R. (1990). A sandwich enzyme immunoassay for bovine interferon- $\gamma$ and its use for the detection of tuberculosis in cattle. Aust. Vet. J. 67 (4), 134-137

70. Rothel, J.S.; Jones, S.L.; Corner, L.A.; Cox, J.C.; Wood, P.R. (1992).The gamma-interferon assay for diagnosis of bovine tuberculosis in cattle: conditions affecting the production of gamma-interferon in whole blood culture. Aust. Vet. J. 69 (1), 1-4.

71. Roxo, E. (2005). Situação Atual da Tuberculose Bovina no Brasil. Plano Nacional de Controle e Erradicação da Brucelose e Tuberculose, PNCE bovine tuberculosis (National Plan For the Control and Eradication of bovine Tuberculosis and Brucellosis). Secretaria de Defesa Agropecuária. Docum. PNCE bovine tuberculosis DDD2005, São Paulo, $1-5$.

72. Ruggiero, A.P.; Ikuno, A.A.; Ferreira, V.C.A.; Roxo, E. (2007). Tuberculose bovina: alternativas para o diagnóstico (Bovine tuberculosis: alternatives for the diagnosis). Arq. Inst. Biol. 74 (1), 55-65.

73. Ryan, T.J.; Buddle, B.M.; De Lisle, G.W. (2000). An evaluation of the gamma interferon test for detecting bovine tuberculosis in cattle 8 to 28 days after tuberculin skin testing. Res. Vet. Sci. 69 (1), 57-61.

74. Salfinger, M.; Pfyffer, G.E. (1994). The new diagnostic mycobacteriology laboratory. Eur. J. Clin. Microbiol. Infect. Dis. 13(11), 961-979.

75. Silva, E. (2001). Evaluation of an enzyme-linked immunosorbent assay in the diagnosis of bovine tuberculosis. Vet. Microbiol. 78 (2), 111-117.

76. Thom, M.; Morgan, J.M.; Hope, J.C.; Ramos, B.V., Martin, M., Howard, C.J. (2004). The effect of repeated tuberculin skin testing of cattle on immune responses and disease following experimental infection with Mycobacterium bovis. Vet. Immunol. Immunopathol. 102 (4), 399-412.

77. Thorel, M.F. (1994). Le role du laboratoire dans le contrôle de la tuberculose chez les animaux. Le Point Vet. 26 (159), 35-40.

78. Vordermeier, H.M.; Rhodes, S.G.; Dean, G.; Goonetilleke, N.; Huygen, 
K.; Hill, A.V.S.; Hewinson, R.G.; Gilbert, S.C. (2004). Cellular immune responses induced in cattle by heterologous prime-boost vaccination using recombinant viruses and bacille Calmette-Guérin. Immunology 112(3), 461-470.

79. Wards, B.J.; Collins, D.M.; Lisle, G.W. (1995). Detection of Mycobacterium in tissues by polymerase chain reaction. Vet. Microbiol. 43 (2-3), 227-240.

80. Waters, R.W.; Palmer, M.V.; Thacker, T.C.; Bannantine, J.P.; Vordemeier, H.M.; Hewinson, R.G.; Greenwald, R.; Esfandiari, J.; McNair, J.; Pollock, J.M.; Andersen, P.; Lyashchenko, K.P. (2006). Early antibody responses to experimental Mycobacterium bovis infection in cattle. Clin. Vac. Immunol. 13(6), 648-654.

81. Welsh, M.D.; Cunningham, R.T.; Corbett, D.M.; Girvin, R.M.; McNair, J.; Skuce, R.A.; Bryson, D.G.; Pollock, J.M. (2005). Influence of pathological progression on the balance between cellular and humoral immune responses in bovine tuberculosis. Immunology 114 (1), 101-111.

82. Whipple, D.L.; Bolin, C.A.; Davis, A.J.; Jarnagin, J.L.; Johnson, D.C.; Nabors, R.S.; Payeur, J.B.; Saari, D.A.; Wilson, A.J. \& Wolf, M.M. (1995). Comparison of the sensitivity of the caudal fold skin test and a commercial gamma-interferon assay for diagnosis of bovine tuberculosis. Am. J. Vet. Res. 56 (4), 415-19.

83. WHO, World Health Organization. (1996). Guidelines for specification withing the Mycobacterium tuberculosis complex. WHO/EMC/ZOO/96.4. Second edition, 23p.

84. Wiker HG. (2009). MPB70 and MPB83--major antigens of Mycobacterium bovis. Scand. J. Immunol. 69(6), 492-9.

85. Wiker, G.H. \& Harboe, M. (1992). The Antigen 85 Complex: a major secretion product of Mycobacterium tuberculosis. Microbiol. Rev. 56 (4), 648-661.

86. Wiker, H. G.; Lyashcenko, K.P.; Aksoy, A.M.; Lightbody, K.A.;
Pollock, J.M.; Komissarenko, S.V.; Bobrovnik, S.O.; Kolesnikova, I.N.; Mykhalsky, L.O.; Gennaro, M.L.; Harboe, M. (1998). Immunochemical characterization of the MPB70/80 and MPB83 proteins of Mycobacterium bovis. Infect. Immun. 66 (4), 1445-1452

87. Wiker, H.G.; Harboe, M.; Lea, T.E. (1986). Purification and characterization of two protein antigens from the heterogenous BCG85 complex in Mycobacterium bovis BCG. Int. Archs. Allergy Appl. Immun. 81 (4), 298-306

88. Wood, P.R \& Rothel, J.S. (1994). In vitro immunodiagnostic assays for bovine tuberculosis. Vet. Microbiol. 40 (1-2), 125-135.

89. Wood, P.R.; Corner, L.A.; Plackett, P. (1990a). Development of a simple, rapid in vitro cellular assay for bovine tuberculosis based on the production of $\square$ interferon. Res. Vet. Sci. 49 (1), 46-49.

90. Wood, P.R.; Rothel, J.S.; McWathers, P.G.D.; Jones, S.L. (1990b). Production and characterization of monoclonal antibodies specific for bovine gamma-interferon. Vet. Immunol. Immunopathol. 25 (1), 37-46.

91. Young, J. S.; Gormley, E.; Wellington,E.M. H. (2005). Molecular detection of Mycobacterium bovis and Mycobacterium bovis BCG (Pasteur) in soil. Appl. Environ. Microbiol. 71(4), 1946-1952.

92. Zanini, M. S; Moreira, E. C; Lopes, M. T. P; Oliveira, R. S; Leäo, S. C; Fioravanti, R. L; Roxo, E; Zumarraga, M; Romano, M. I; Cataldi, A; Salas, C. E. (2001). Mycobacterium bovis: polymerase chain reaction identification in bovine Lymphonode biopsies and genotyping in isolates from Southeast Brazil by spolygotyping and restriction fragment length polymorphism. Mem. Inst. Oswaldo Cruz 96(6), 809-813.

93. Zumárraga, M. J.; Martin, C.; Samper, S.; Alito, A.; Latini, O.; Bigi, F.; Roxo, E.; Cicuta, M.E.; Errico, F.; Ramos, M.C.; Cataldi, A.; Soolingen, D, Romano, A.A. (1999). Usefulness of spoligotyping in molecular epidemiology of Mycobacterium bovis-related infectious in South America. J. Clin. Microbiol. 37 (2), 296-303. 